\title{
КОНТРОЛЬ ЗА ВИКОНАННЯМ РЕЛІГІЙНИМИ ГРОМАДАМИ ЗАКОНОДАВСТВА ПРО РЕЛІГІЙНІ КУЛЬТИ: ДОСВІД УКРАЇНСЬКОЇ РСР (70-ТІ - 80-ТІ РОКИ ХХ СТОЛІТТЯ)
}

\begin{abstract}
Анотація. У статті здійснено ретроспективний аналіз характеру, особливостей проявів порушення законодавства про релігійні культи в Українській РСР у період розвинутого соціалізму, дослідження форм та методів боротьби радянських партійно-державних органів влади із цими явищами. Наведені конкретні приклади порушення віруючими законодавства про релігійні культи. Відзначено, що компартійні документи із грифом "таємно» дозволяють констатувати, що партійно-державні органи влади УРСР у 1960-х - 1980-х рр. не досягли особливих успіхів у питанні контролю за дотриманням законодавства про релігійні культи, особливо у західноукраїнських областях. Окреслену тезу яскраво підтверджують численні листи віруючих до партчиновників з вимогами відкрити закриті культові спору, зарееструвати ліквідовані / нові релігійні громади, спроби релігійних активістів самовільно відкрити недіючі культові споруди в окремих місцевостях УРСР, впровадження у побут релігійної обрядовості тощо.
\end{abstract}

Ключові слова: УРСР, КПУ, законодавство про релігійні культи, адміністративні штрафи, репресії, переслідування, віруючі.

Puyda Roman

Ivano-Frankivsk National Technical University of Oil and Gas

\section{MONITORING THE RELIGION OF RELIGIOUS CULT LAWS BY RELIGIOUS COMMUNITIES: EXPERIENCE OF THE UKRAINIAN SSR (70S-80S OF THE XX CENTURY)}

Summary. The article provides a retrospective analysis of the nature, features of violations of the law on religious cults in the Ukrainian SSR during the period of advanced socialism, a study of forms and methods of struggle of the Soviet party-state authorities with these phenomena. The methodological basis of the article is the principles of historicism, systematics and objectivity in the approach to the coverage of past events on the basis of a comprehensive study of sources and scientific literature. In solving the tasks used general scientific (systematization, typology, retrospection), special-historical (problem-chronological, historical-comparative, critical-analytical, biographical) methods. The investigation provides specific examples of violations of the law on religious cults by believers, reveals mechanisms for counteracting the party-state apparatus to spread the influence of religion on the population of the region, established the effectiveness of scientific and atheistic propaganda of central and local Soviet authorities. It is noted that the party documents marked "secret" allow us to state that the party-state authorities of the USSR in the 1960s and 1980s did not achieve much success in monitoring compliance with the law on religious cults, especially in western Ukraine. This thesis is clearly confirmed by: numerous letters from believers to party officials demanding to open closed religious disputes, to register liquidated / new religious communities, attempts of religious activists to arbitrarily open non-functioning religious buildings in some areas of the USSR, underground ordination of the clergy, etc. It was found that in order to counteract the spread of religiosity among the population of the republic, the CPU widely used the methods of atheistic propaganda, applied repressions to the most active believers and clergy. It is proved that the refusals of local authorities to register religious communities, the inability to perform religious rites due to repression and persecution, the reluctance of party officials to solve numerous problems of believers created tensions in the sphere of state-church relations, escalated into open confrontation of believers with state-party authorities. Keywords: USSR, CPU, legislation on religious cults, administrative fines, repressions, persecution, believers.

$\Pi$ остановка проблеми. Політика радянської держави щодо релігійних церков і спільнот упродовж другої половини XX ст., за винятком декількох коротких періодів, була безперервним наступом влади на духовні інституції 3 метою обмеження або заборони їх функціонування. Першочерговим завданням релігійних громад у такій ситуації стала спроба вироблення такої моделі співпраці з владою, яка б дозволила функціонувати в офіційно атеїстичній державі. Виняток - греко-католики, свідки Єгови, дрібні релігійні групи, які радянсько-партійні органи влади таврували як зрадників, ворогів радянського народу. Відмови місцевих органів влади у реестрації релігійних громад, відсутність можливості здійснення релігійних обрядів, зважа- ючи на репресії та переслідування, небажання партчиновників вирішувати численні проблеми віруючих породжували напругу у сфері державно-церковних відносин, переростали у відкриту конфронтацію віруючих із державно-партійними органами влади.

Аналіз останніх досліджень і публікацій. Державно-церковні відносини в УРСР уже не перший рік перебувають у полі зору українських істориків, релігіезнавців, філософів, політологів, які упродовж останніх тридцяти років розкрили окремі аспекти проблеми. Узагальнюючі наукові студії учених загалом відображають загальну картину політики Центрального Комітету Комуністичної партії Радянського Союзу (ЦК КПРС) у релігійній сфері, що зокрема помітно у дослі- 
дженнях О. Бажана, Ю. Данилюка [1], П. Бондарчука [2], В. Войналовича [3], В. Марчука [3], В. Пащенка [4] та ін., проте не у них не достатньо уваги приділено проблемі кондронтації віруючих із державно-партійними органами влади.

Мета статті - розглянути особливості проявів порушення законодавства про релігійні культи в Українській РСР у період розвинутого соціалізму, дослідження фором та методів боротьби радянських партійно-державних органів влади із цими явищами.

Виклад основного матеріалу дослідження. Релігія відігравала надзвичайно важливу роль на всіх етапах українського державотворення. Встановлення радянської влади привело до абсурдної заборони на сповідування віри своїх батьків, що у період «брежнівського застою» породило численні конфронтації віруючих та партійно-державних органів влади. У досліджуваний період радянські документи фіксують тисячі фактів порушення законодавства про релігійні культи віруючими, особливо західноукраїнського регіону, базовими із яких стали: (а) самовільне відкриття культових споруд; (б) самовільне відновлення діяльності релігійних громад.

Передусім наголосимо, що для задоволення релігійних потреб віруючі нерідко усупереч діючому законодавству самовільно відкривали культові споруди. Так, у 1969 р. у селі Пиняни Самбірського району Львівської області віруючими греко-католиками були зібрані кошти, за допомогою яких вони зуміли провести внутрішній ремонт церкви і «встановили контакт з уніатськими священиками, які стали регулярно відправляти у ній богослужіння» [6, арк. 23]. 14 листопада 1969 р. після чергової літургї, віряни були оточені нарядом міліції із Самбора, однак після сутичок «наряд міліції був витіснений громадою і уніатам вдалося втекти» [6, арк. 24].

У 1978 р. жителі села Угринів Коломийського району Івано-Франківської області самостійно повністю перекрили дах місцевої церкви, заготовили будівельний матеріал для подальшого ремонту. Районне керівництво, за словами старшого інспектора Ради у справах релігій при Раді Міністрів УРСР В. Середи, зловтішалися тим, що на Великдень 1981 р. місцеві віруючі не провели молитовне зібрання. Насправді, відзначав чиновник, богослужіння не відбулося тільки тому, що віруючі завершували ремонт церкви [7, арк. 21].

У лютому 1981 р. віруючі РПЦ села Тарасівка Збаражзького району Тернопільської області звернулася до Ради у справах релігій при Раді Міністрів УРСР з вимогою дозволити їм хоча б раз у рік проводити на Великдень богослужіння у місцевій сільській Церкві. Ще в 1980 р. мешканці села розпочали ремонт у церкві, хоча голова виконкому сільської ради О. Шмигельська запропонувала припинити ремонт. Додому, що релігійна громада не фрункціонувала із 60 -х років XX століття, а місцева Церква не використовувалась зважаючи на відсутність священика [7, арк. 46].

У 1981 р. із Калуського району Івано-Франківська область почали поступати заяви з вимогою відкриття церков. Основна причина такого явища, на думку партчиновників, - послаблення контролю за дотриманням законодавства, недостатня виховна робота 3 віруючими, безприн- ципність окремих посадових осіб, а також наявність 17 неосвоєних культових споруд. У районі діяли 7 неофіційних православних громад із 13, які фонкціонували в області. Уповноважений ради у справах релігій при Раді Міністрів УРСР відзначав, що свою діяльність вони розпочали «в останні роки після захоплення віруючими неосвоєних культових споруд” [7, арк. 20]. Під час Великодніх свят молитовні збори відбулися в таких населених пунктах, як Голинь, Добровляни, Копанки [7, арк. 21]. Найскладнішою для Компартії України залишалася ситуація у селі Голинь Коломийського району Івано-Франківської області, де місцеві віруючі цілодобово охороняли захоплену культову споруду. Під час проведення молитовних зібрань віруючі користувалиться греко-католицькою атрибутикою, зокрема самвидавом. Для внутрішнього освітлення споруди використовуеться акумуляторна батарея. Під час богослужіння священнослужитель нерідко вимагає узаконити діяльність цього релігійного об'єднання [7, арк. 21].

Нерідко релігійні громади, знятті з реєстращії у 1960-х роках, на початку 1980 -х років самовільно відновлювали свою діяльність. Для прикладу, у селі Рудники Маневського району Волинської області уповноважений ради у справах релігій при Раді Міністрів УРСР намагався ліквідувати місцеву релігійну громаду, яка 31978 р. Значно активізувала свою діяльність і почала добиватися офріційної реєстрації. Він зауважував, що райком партії, райвиконком, партійні та радянські органи «зуміли виявити франатично налаштованих осіб і добилися значного зниження їх активності. У селі проводиться виховна робота серед основних груп населення - механізаторів, пенсіонерів, інвалідів Великої Вітчизняної Війни, домогосподарок. $\mathrm{У}$ результаті, за його словами, у цьому населеному пункті залишилася тільки незначна група віруючих, яка продовжуе періодично писати листи до центральних органів влади» [7, арк. 43].

Чимало проблем для місцевих партчновників створювали незареєстровані релігійні громади. Так, уповноважений Ради у справах релігій при Раді Міністрів УРСР у Тернопільській області Г. Боженко повідомляв, що спільно із радянськими органами влади проводиться робота щодо припинення діяльності незареєстрованих релігійних громад РПЦ в області. Однак незважаючи на вжиті заходи вагомих результатів у цьому напрямі не було досягнуто. У 1981 р., зокрема, було заплановано припинити масові моління у дев'яти культових приміщеннях. У першому кварталі була припинена діяльність релігійної громади у селі Гнилиці Підволочиського району і Костильники Бучацького району. Водночас у другому кварталі 1981 р. ні в одному з запланованих населених пунктів припинити діяльність релігійних громад не вдалося [7, арк. 47].

$\mathrm{У}$ доповідній записці «Про заходи щодо припинення нелегальної діяльності релігійних груп п'ятидесятників та інших сектантських течій» (1976 р.) рівненський обком Компартії України повідомляв, що в області проведено значну роботу щодо припинення діяльності релігійних груп еговістів, адвентистів сьомого дня, п'ятидесятників, а також послідовників, які підтримують так звану Раду церков євангель- 
ських християн-баптистів. За даними обкому Компартії Україна у 1975 році припинили свою діяльність групи еговістів в селищі Березне і селищі Демидівка Млинівського району Рівненської області. Значно знизили активність групи еговістів у Костопільському і Рівненському районах. На думку партчиновників 3 року в рік зменшуеться кількість віруючих, які знаходяться під впливом п'ятидесятники. У низці сіл області, констатували в обкомі Компартії України, «групи п'ятидесятників припинили свою нелегальну антигромадську діяльність і тепер відкрито проводять молитовні зібрання, відмовившись при цьому від шкідливих обрядів», а діти п'ятидесятників не відмовляються від військової служби в радянській армії, активні члени піонерських і комсомольських організацій. Водночас нелегальні групи п'ятидесятників продовжували діяти у Сарненському, Березівськом,у Костопільському, Рівненському, Дубнівському, Здолбунівському районах і місті Рівне [8, арк. 22].

Констатовано, що «вивчення діяльності груп п'ятидесятників показуе, що на місцях зі сторони окремих місцевих органів влади і комісій сприяння місцевим радам щодо контролю за дотриманням законодавства про релігійні культи, не дивлячись на наші [Рівненського обкому Компартії України - авт.] рекомендації, ще слабо і безсистемно ведеться необхідна профілактична робота щодо переконання віруючих їх керівників до переходу в зареестровані громади євангельських християн баптистів і припинення тим самим їх антигромадської нелегальної діяльності. В Обкомі Компартії України (Рівненська область) відзначали, що там де п'ятидесятнищі групи припинили свою нелегальну діяльність і просили про реестрацію у місцевих органів влади, останні здебільшого не розглядають у законному порядку заяви про реестрацію в продовжують діяти в «не зовсім виправданих рамках правового поля», а саме відмовляють в реестрації з малопереконливими мотивами або ж продовжують накладати штрафи нібито за самовільне проведення п'ятидесятниками своїх молитовних зібрань [8, арк. 23].

Рівненський облвиконком своїм рішенням від 25 квітня 1974 року зобов'язав Березівський райвиконком "вжити відповідних заходів щодо припинення незаконної діяльності протестантів села Поляни». Однак бажаних успіхів і результатів для Компартії України у цьому питанні не досягнуто. У підсумку, віруючі не тільки не знизили активності, а щілими групами відвідували союзні, республіканський партійні і радянські органи 3 вимогою реєстрації громади євангельських християн баптистів у селі Поляни. Радянська / республіканська ради у справах релігій, враховуючи активність віруючих села Поляни не погодилися 3 рішенням райвиконкому і облвиконкому і відповідно до Положення про Ради у справах релігій, усупереч рішенням місцевих органів влади, зобов'язали останніх переглянути рішення і зарееструвати релігійну общину евангельських християн-баптистів у селі Поляна. У Раді у справах релігій при Раді Міністрів УРСР відзначили, що у Волинській, Житомирській, Київській областях місцеві органи влади «для розрядки ситуації, в окремих випадках" рееструють релігійні громади [8, арк. 25].
Загалом у Рівненській області станом на 23 серпня 1976 р., за даними Уповноваженого Ради у справах релігій при Раді Міністрів СРСР у Рівненській області Г. Личковахи, нараховувалося 12 незареестрованих груп п'ятидесятників, із яких сім груп не подавали заяв на реестрацію і не виявляли бажання переходити до зареестрованих релігійних громад євангельських християн-баптистів. Такі релігійні групи діяли у селах Бистричі, Вітковичі Березівського району, Кричильськ, Тинне-Чабель Сарненського району, Шпанів-Рівне, Волошки-Черепашник і Бегень Рівненського району Рівненської області. Уповноважений ради у справах релігій зазначав, що наприкінці 1975 року посилилась тенденщія до «утворення окремих автономних п'ятидесятницьких груп і навіть виходу окремих релігійних груп із зареєстрованих релігійних громад євангельських християн-баптистів» [8, арк. 29].

Планом роботи апарату уповноваженого ради у справах релігій при Раді Міністрів УРСР щодо припинення діяльності релігійних громад, які не перебували на реестрації в Івано-Франківській області на 1981-1985 роки передбачалося: 1. Припинити діяльність незареестрованих релігійних громад у наступні терміни: 1981 рік село Кунисівці Городенківського району, а також селах Верхня і Слобідка Калушського району; 1982 рік - село Марків Богородчанського району, село Топорівці Городенківського району, село Узин Івано-Франківського району; 1983 рік село Брошнів Рожнятівського району; 1984 рік село середній Угринів і Добровляни Калушського району; 1985 рік - село Голинь Калушського району і селище Перегінськ Рожнятівського району, село Кривець Богородчанського району. 2. Освоїти недіючі культові споруди: 1982 рік - село Марків Богородчанського району (музей), села Топорівці і Кунисівці Городенківського району (музеї), село Вехня і Слобідка Калуського району (музей, склад відповідно); 1983 рік - село Узин Івано-Франківського району (знести), село Брошнів Рожнятівського району (музей); 1984 рік село Перегінськ Рожнятівського району (музей); 1985 рік - село Середній Угринів, село Добровляни і село Голинь Калушського району (склад, спортзал і музей відповідно), село Кривець Богородчанського району (музей). У цей же час планувалося відкрити православні церкви у 12 населених пунктах області [7, арк. 93].

Серед порушників радянського законодавства про релігійні культи значну увагу державнопартійні органи влади приділяли греко-католикам. Так, в «Інформації про процеси і тенденції в середовищі залишків прихильників колишньої уніатської церкви» уповноважений ради релігій в Івано-Франківській області повідомляв, що «уніатські авторитети як і раніше сподіваються на відновлення діяльності колишньої уніатської церкви». Зважаючи на цей фракт, вони «дотримуються уніатського віровчення і обрядовості, підтримують між собою контакти, монахині проживають маленькими групами по 2-3 особи...» [9, арк. 63]. Окремі священнослужителі - М. Волосянко, М. Сімкайло «прямо ставлять питання про реєстрацію об’єднань віруючих греко-католицького віровчення» [9, арк. 63]. Священнослужителі (М. Волосянко, М. Сімкайло, М. Остапяк, О. По- 
горецький, С. Дмитерко, Г. Гаєцький, М. Матійцев, М. Косило, П. Чучман, М. Остапяк, Р. Проців, В. Корніцький та ін.) проводять релігійні обряди [9, арк. 61]. Загалом відзначимо, що тільки в Івано-Франківській області на початку 1980-х рр. проживало 47 священнослужителів [9, арк. 62].

У цьому контексті у місцевих органів влади виникало чимало запитань до ефрективності роботи атеїстичних бригад, лекторів-агітаторів. Для прикладу, у селі Пороги (Івано-Франківська область) комісія за контролем щодо дотримання законодавства про культи (голова - В. Дроздик) відповідно до звітних документів «займалася постійною атеїстичної роботою». Про ефективність такої роботи красномовно свідчать фракти: у 1982 році із 69 новонароджених дітей, 67 були хрещені, а 328 зареєстрованих шлюбів, 21 подружня пара вінчалися у Церкві. У селі Марків (Івано-Франківська область) із 53 новонароджених, 29 -хрещені (54 відсотки), із 17 зареєстрованих шлюбів, 8 подружніх пар і вінчалися у Церкві села Манява. Із 19 померших у 1982 році тільки два члени КПРС М. Мундяк і М. Кріца були похоронені відповідно до радянської обрядовості, хоча й у цих випадках згодом на їх могилах обеліски були замінені на хрести [10, арк. 162].

Бюро Львівського обкому Компартії України вважало, що районі комітети партії радянський та адміністративні органи Городоцького, Стрийського, Яворівського районів недооцінили серйозність дії екстремістів уніатів щодо їх спроб активізувати католицьку церкву, відновити уніатство втратили, політичну гостроту в цих питаннях, допустили грубі прорахунки у виховній роботі серед населення. Тривалий час у селах Мишана, Завадів, Мужиловичі прихильники уніатства проводили масові збори на релігійному грунті, створювали конфліктні ситуащії, постійно порушували громадський порядок, запрошували для задоволення релігійних потреб колишніх уніатських священиків [11, арк. 2].

Районні комітети партії своєчасно не дали принципової оцінки протизаконним діям «залишків уніатства», не забезпечили чіткої координащії зусиль партійних організацій, радянських адміністративних органів. Громадський актив цих сіл вів себе пасивно, втратив політичну пильність, не інформував партійні, радянські органи про положення, яке створилося у вказаних селах, не протидіяв спробам релігійних екстремістів відновити уніатство. Політико виховна робота в Завадові, Мшані,Мужиловичах, як і в інших селах цих районів, велася формально, була занедбана індивідуальна робота з віруючими, зовсім не використовувалися громадська думка трудових колективів де працювали уніати [11, арк. 2].

Зважаючи на складну релігійну ситуацію, Львівський Обком Компартії України вважав необхідним: 1. Провести обласні міські, районні семінари-практикуми партійно-радянського ідеологічного активу у питаннях контролю за дотриманням законодавства про культи, припинення спроб активізувати Католищьку Церкву і відновити уніатство; 2. Обговорити на бюро міськомів, райкомів партії питання про перебудову атеїстичного виховання населення, посилення контролю за дотриманням законодавства про культи, припинення діяльності «залишків уніатства»; 3. Взяти на особливий облік усіх прихильників уніатства, релігійного франатизму та екстремізму, організувати з ними конкретно цілеспрямовану ідеологічну роботу. Створити в населених пунктах оперативні групи 3 числа працівників радянських, адміністративних органів, членів добровільних народних дружин (ДНД) і ідеологічного активу; 4. В усіх населених пунктах, де проявляли активність уніати, проаналізувати діяльність установ культури, народної освіти, зміцнити їх матеріальну базу, встановити щоквартальний контроль за ходом виконання накреслених заходів [11, арк. 2].

Якщо подивитися на географрію поширення греко-католицького руху у Львівській області, підстави для паніки у партійного керівництва області справді були. Так, серед населених пунктів Львівської області, де проявляли активність греко-католицькі віруючі Львівський, Обком Компартії України виокремив такі села: Бродівський район - Пеняки, Маркопіль, Стиборівка та ін.; Буський район - Олесько, У тішків, Кудрявці; Городоцький район - Кліцько, Добряни, Березець, Путятичі, Зелений Гай, Нове Село, Градівка, Мости та ін.; Дрогобицький район - Верхні Гаї, Смільне, Биків, Снятинка та ін.; Золочівський район - Поморяни, Зозулі, Вороняки та ін.; Кам'янко-Бузький район - Колоденці, Жовтанці, Желдець та ін.; Миколаївський район - Старий Розділ, Бродки, Новий Розділ, Пісочне, Вербіж та ін.; Мостиський район - Зав'язанщі, Хоросниця, Заріччя, Судова Вишня та ін.; Жовківський (у 1981 р. - Нестерівський) район - Боянець, Деревня, Зашків, В'язова, Забір'я, Зарудці та ін.; Перемишлянський район - Ладанці, Тучне, Вовків, Бібрка та ін.; Пустомитівський район - Давидів, Водяне, Сокільники, Старе Село та ін.; Радехівський район - Криве, Поздимир, Нестаничі та ін.; Самбірський район - Подільці, Підгайчики, Вістовичі, Бісковичі, Задністряни та ін.; Сколівський район - Верхне Синевидне, Труханів, Ямельниця та ін.; Сокальський район Бендюга, Воловин, Добрячин та ін.; Стрийський район - Завадів, Грибівці, Дідушичі, Воля, Монастирець та ін.; Турківський район - Мохнате, Матків; Яворівський район - Мужиловичі Добровиця, Калинівка, Рясне та ін. [11, арк. 12].

На початку 80-х років XX століття значна активність віруючих помітна у Закарпатській області. Зокрема у 1980 році за порушення законодавства про релігійні культи було притягнуто до адміністративної відповідальності трьох представників протестантських громад та однієї православної (порушники законодавства платили штрафр від 25 до 50 рублів). У 1981 році зафріксовано уже 15 випадків порушення законодавства. Уповноважений Ради у справах релігій після візиту у Закарпатську область був змушений визнати, що у місцевих виконкомах, сільських радах не знають точної кількості віруючих незареєстрованих релігійних громад. Більше того, місцеві органи влади називають у своїх документах євангельських християн баптистів і п'ятидесятниками і п'ятидесятниками-суботниками і просто баптистами-суботниками. «Кваліфрікованої різниці між різними релігійними групами немає», - резюмував М. Шостак [10, арк. 36].

Висновки 3 даного дослідження i перспективи. У досліджуваний період в УРСР ра- 
дянсько-партійні органи влади фріксували значну кількість порушень законодавства про релігійні культи представниками православних, католицьких, протестантських конфесій, що підтверджувало фракт збереження високої релігійності населенням республіки. Активна діяльність віруючих викликала опір місцевих партчиновників, які були змушені вдаватися до нових форм протидії, серед яких - посилення атеїстичної роботи, заборона реєстрації окремих релігійних громад, закриття культових споруд, переслідування активних релігійних активістів тощо. Зважаючи на поверхневість роботи комуністичних активістів окреслені заходи не приносили очікуваних для Компартії України результатів, сприяли поглибленню кризи у державно-церковних відносинах. Перспективний напрям подальших досліджень - боротьба КПУ з релігійністю населення у західноукраїнських областях у період розвинутого соціалізму.

\section{Список літератури:}

1. Бажан О., Данилюк В. Випробування вірою: боротьба за реалізацію прав і свобод віруючих в Україні в другій половині 1950-1980-х рр. Київ, 2000. 329 с.

2. Бондарчук П. Релігійна свідомість віруючих УРСР (1940-1980-і роки): повсякденні прояви, трансформації. Київ, 2012. 321 с.

3. Войналович В. Партійно-державна політика щодо релігії та релігійних інституцій в Україні 1940-1960-х років: політологічний дискурс. Київ, 2005. 741 с.

4. Марчук В. Церква, духовність, нація. Українська греко-католицька церква в суспільному житті України ХХ ст. Івано-Франківськ, 2004. 464 с.

5. Пащенко В. Греко-католики в Україні. Від 40-х рр. ХХ ст. до наших днів. Полтава, 2002. 616 с.

6. ДАЛО. Ф. Р-1332. Оп. 2. Спр. 43. 115 арк.

7. ЦДАВО України. Ф. 4648. Оп. 6. Спр. 162. 98 арк.

8. ЦДАВО України. Ф. 4648. Оп. 7. Спр. 127. 150 арк.

9. ДАІФО. Ф. Р-338. Оп. 1. Спр. 48. 178 арк.

10. ЦДАВО України. Ф. 4648. Оп. 8. Спр. 207. 202 арк.

11. ДАЛО. Ф. П-3. Оп. 58. Спр. 63. 67 арк.

\section{References:}

1. Bazhan O., Danyljuk V. (2000) Vyprobuvannja viroju: borotjba za realizaciju prav i svobod virujuchykh v Ukrajini v drughij polovyni 1950-1980-kh rr. [The Test of Faith: The Struggle for the Realization of the Rights and Freedoms of Believers in Ukraine in the Second Half of the 1950s and 1980s]. Kyiv. (in Ukrainian)

2. Bondarchuk P. (2012) Relighijna svidomistj virujuchykh URSR (1940-1980-i roky): povsjakdenni projavy, transformaciji [Religious consciousness of believers of the USSR (1940-1980s): everyday manifestations, transformations]. Kyiv. (in Ukrainian)

3. Vojnalovych V. (2005) Partijno-derzhavna polityka shhodo relighiji ta relighijnykh instytucij v Ukraini 1940-1960-kh rokiv: politologhichnyj dyskurs [Party-State Policy on Religion and Religious Institutions in Ukraine in the 1940s and 1960s: Political Science Discourse]. Kyiv. (in Ukrainian)

4. Marchuk V. (2004) Cerkva, dukhovnistj, nacija. Ukrajinsjka ghreko-katolycjka cerkva v suspiljnomu zhytti Ukrajiny KhKh st. [Church, spirituality, nation. Ukrainian Greek Catholic Church in the public life of Ukraine in the twentieth century]. Ivano-Frankivsjk. (in Ukrainian)

5. Pashhenko V. (2002) Ghreko-katolyky v Ukraini. Vid 40-kh rr. XX st. do nashykh dniv [Greek Catholics in Ukraine. From the 40's of the twentieth century. to this day]. Poltava. (in Ukrainian)

6. DALO. F. R-1332. Op. 2. Spr. 43. 115 ark.

7. TsDAVO Ukrainy. F. 4648. Op. 6. Spr. 162. 98 ark.

8. TsDAVO Ukrainy. F. 4648. Op. 7. Spr. 127. 150 ark.

9. DAIFO. F. R-338. Op. 1. Spr. 48. 178 ark.

10. TsDAVO Ukrainy. F. 4648. Op. 8. Spr. 207. 202 ark.

11. DALO. F. P-3. Op. 58. Spr. 63. 67 ark. 